\title{
Production and characterization of monoclonal antibodies against Campylobacter fetus subsp. venerealis ${ }^{1}$
}

\author{
Telma M. Alves², Luiz G.D. Heneine³ ${ }^{3}$ Bárbara S. Araújo², Luciana M. Silva4, Patrícia \\ C. Campos ${ }^{3}$, Márcia S. Hermogenes ${ }^{4}$ and Andrey P. Lage ${ }^{2 *}$
}

\begin{abstract}
Alves T.M., Heneine L.G.D., Araújo B.S., Silva L.M., Campos P.C., Hermogenes M.S. \& Lage A.P. 2012. Production and characterization of monoclonal antibodies against Campylobacter fetus subsp. venerealis. Pesquisa Veterinária Brasileira 32(7)640644. Laboratório de Bacteriologia Aplicada, Departamento de Medicina Veterinária Preventiva, Escola de Veterinária, Universidade Federal de Minas Gerais. Av. Antônio Carlos 6627, Cx. Postal 567, Belo Horizonte, MG 30123-970, Brazil. E-mail: alage@vet.ufmg.br

Myeloma cells Sp2/0-Ag14 and spleen cells from BALB/c mouse immunized with sonicated Campylobacter fetus subsp. venerealis NCTC 10354 were fused with polyethylene glycol (PEG) for the selection of clones producing antibodies. Clones were obtained by limiting dilution and screened for the production of specific antibodies to $C$. fetus subsp. venerealis NCTC 10354 by indirect ELISA and western blot against a panel of bacteria: $C$. fetus subsp. venerealis NCTC 10354, C. fetus subsp fetus ADRI 1812, C. sputorum biovar sputorum LMG 6647, C. lari NCTC 11352, and Arcobacter skirrowii LMG 6621 for the ELISA and $C$. fetus subsp. venerealis NCTC 10354 and $C$. sputorum biovar sputorum LMG 6647 for the western blotting. Fifteen clones producing monoclonal antibodies (MAbs) anti- $C$. fetus subsp. venerealis of the IgM (1) and IgG (14) classes were further screened for species-specificity. Four clones of the 15 obtained were producers of species-specific monoclonal antibodies (MAbs): two were specific for $C$. fetus subsp. venerealis and two were specific for $C$. fetus subsp. fetus. None of the clones were reactive against $C$. sputorum biovar sputorum LMG 6647. All clones recognized a protein with molecular mass of approximately $148 \mathrm{kDa}$ from lysed $C$. fetus subsp. venerealis NCTC 10354.

INDEX TERMS: Monoclonal antibodies, Campylobacter fetus subsp. venerealis, cattle, bovine genital campylobacteriosis.
\end{abstract}

RESUMO.- [Produção e caracterização de anticorpos monoespecíficos contra Campylobacter fetus subsp. venerealis.] Para a produção de anticorpos monoclonais contra Campylobacter fetus subsp. venerealis foram utilizadas as linhagens de células de mieloma Sp2/0-Ag14 e células de baço de camundongos BALB/c imunizados com soni-

\footnotetext{
${ }^{1}$ Received on December 13, 2011.

Accepted for publication on March 10, 2012.

${ }^{2}$ Laboratório de Bacteriologia Aplicada, Núcleo de Pesquisa em Saúde Animal, Departamento de Medicina Veterinária Preventiva, Escola de Veterinária, Universidade Federal de Minas Gerais (UFMG), Av. Antônio Carlos 6627, Cx. Postal 567, Belo Horizonte, MG 30123-970, Brazil. *Corresponding author: alage@vet.ufmg.br

${ }^{3}$ Laboratório de Imunologia e Bioprodutos, Fundação Ezequiel Dias (Funed), Rua Conde Pereira Carneiro 80, Bairro Gameleira, Belo Horizonte, MG 30510-010.

${ }^{4}$ Laboratório de Biologia Celular e Molecular, Funed, Belo Horizonte, MG.
}

cado de $C$. fetus subsp. venerealis NCTC 10354. A detecção dos anticorpos monoclonais foi realizada por ELISA indireto utilizando antígeno sonicado de $C$. fetus subsp. venerealis NCTC 10354. A clonagem foi realizada por diluição limitante e os clones foram caracterizados por ELISA indireto utilizando um painel de bactérias escolhidas em função da prevalência e habitats: $C$. fetus subsp. venerealis NCTC 10354, C. fetus subsp. fetus ADRI 1812, C. sputorum biovar sputorum LMG 6647, C. lari NCTC 11352 e Arcobacter skirrowii LMG 6621; e no "western blotting" utilizando antígenos sonicados de $C$. fetus subsp. venerealis NCTC 10354 e C. sputorum biovar sputorum LMG 6647. Foram obtidos 15 clones produtores de anticorpos anti- $C$. fetus subsp. venerealis das classes IgM (1) e IgG (14). Quatro clones dentre os 15 clones obtidos foram produtores de anticorpos monoclonais espécie-específicos: dois clones reagiram com maior especificidade contra $C$. fetus subsp. venerealis NCTC 10354 e dois clones reagiram com maior especificidade 
contra C. fetus subsp. fetus ADRI 1812. Nenhum dos clones reagiu contra $C$. sputorum biovar sputorum LMG 6647, comprovando a especificidade dos anticorpos monoclonais testados. Todos os clones reconheceram uma proteína de massa molecular de aproximadamente $148 \mathrm{kDa}$ no sonicado de $C$. fetus subsp. venerealis NCTC 10354.

TERMOS DE INDEXAÇÃO: Anticorpos monoclonais, Campylobacter fetus subsp. venerealis, bovinos, campilobacteriose genital bovina.

\section{INTRODUCTION}

Campylobacter fetus is a Gram-negative, microaerophilic bacterium, classified into two closely related subspecies, C. fetus subsp. fetus and C. fetus subsp. venerealis. It is the causative agent of different diseases in man, cattle and sheep. Genital campylobacteriosis is a sexually transmitted disease, with a worldwide distribution, that affects cattle resulting in great economic loss due to the reproductive problems it produces (Blaser et al. 2008, Alves et al. 2011).

The habitat of $C$. fetus subsp. venerealis is the genital tract of cattle where the microorganism is found predominantty in the epithelial crypts of prepuce and penis and the epithelia of vagina and uterus, and is responsable for repeated breedings and abortions. In contrast, the habitat of C. fetus subsp. fetus is the gastrointestinal tract, and is the cause of abortion in sheep and sporadic abortion in cattle (Stoessel 1982, Blaser et al. 2008).

In Brazil, about $20 \%$ of beef bulls are infected with $C$. $f e$ tus and $50.8 \%$ of the beef herds have infected animals, but in some regions those prevalences were higher than $50 \%$ and $85 \%$, respectively, indicating a wide distribuition of $C$. fetus subsp. venerealis in the country (Alves et al. 2011).

In 1975, in England, Köhler and Milstein reported the production of monoclonal antibodies (MAbs) with high specificity for a given epitope. From then on, antibodies with homogeneous and high specificity for a single epitope could be obtained. The aim of the present study was to produce and characterize MAbs against $C$. fetus subsp. venerealis.

\section{MATERIAS AND METHODS}

Animals. Female BALB/c mice aged between 4 and 6 weeks were purchased from the Centro de Bioterismo do Instituto de Ciências Biológicas (ICB) from Universidade Federal de Minas Gerais (UFMG) and used for the MAbs production. Specific pathogen free (SPF) female Swiss mice, used for the removal of peritoneal macrophages, were obtained from the animal facility of Fundação Ezequiel Dias (Funed).

The project was approved by the Ethics Commitee in Animal Experimentation (Cetea/UFMG) by the protocol no $124 / 04$. All animal manipulation followed humane rules for animal handling (AVMA 2001).

Bacterial strains and culturing conditions. Arcobacter skirrowii LMG6621 (Laboratorium voor Microbiologic, Rijksuniversiteit Gent, Belgium), Campylobacter fetus subsp. fetus ADRI 1812 (Animal Diseases Research Institute, Canada), C. fetus subsp. venerealis NCTC10354 (National Type Culture Collection, England), C. hyointestinalis subsp. hyointestinalis LCDC17398 (Laboratory Center for Disease Control, Canada), C. lari NCTC 11351, and C. sputorum biovar sputorum LMG 6647 were cultured in Brain He- art Infusion Agar (BHI, Difco, EUA), supplemented with 10\% horse blood, under microaerophilic condition $\left(5 \% \mathrm{O}_{2}, 5 \% \mathrm{H}_{2}, 10 \%\right.$ $\mathrm{CO}_{2}$ and $80 \% \mathrm{~N}_{2}$ ) at $37^{\circ} \mathrm{C}$ for $48 \mathrm{~h}$ (Debruyne et al. 2008). Bacterial cells were havested and suspended in phosphate buffered saline (PBS) $\mathrm{pH} 7.4$, standardized to the McFarland nephelometer 10 scale and sonicated (Sonics Vibra Cell ${ }^{\mathrm{T}}$, USA) in ice for 6 cicles of 30 second each, with 1 minute intervals. The frequence used was $50 \mathrm{kHz}$ and a bacterial lysis of $60 \%$ was established as optimal. The sonicated antigen was stored at $-80^{\circ} \mathrm{C}$. The concentration of proteins was determined by the method of Lowry et al. (1951).

Immunization of mice. BALB/c female mice were immunized with the sonicated antigen of the $C$. fetus subsp. venerealis strain NCTC 10354, emulsified in Freund's complete adjuvant (Sigma, USA) (first inoculation) and Freund's incomplete (Sigma, USA) (second and third inoculations) in the proportion of 1:2. The inoculated volumes were of $500 \mu \mathrm{L}$ containig $50 \mu \mathrm{g}$ of antigen and the intraperitoneal route was employed at days 0,15 and 30 . A fourth inoculation was performed by the intravenous or subcutaneous route, with $50 \mu \mathrm{g}$ of the antigen in $100 \mu \mathrm{L}$ of PBS without adjuvant, four days before removal of the spleen, for B cells sincronization (Harlow \& Lane 1988).

Preparing spleen cells. BALB/c mice were sacrificed by cervical dislocation (AVMA 2001) four days after the final boost, and spleen was removed and washed three times with RPMI 1640 medium (Invitrogen, USA) supplemented with $10 \mathrm{mg} / \mathrm{mL}$ tetracycline (Sigma, USA), 1mg/mL amphotericin B (Bristol-Myers Squibb, Brazil) and $40 \mathrm{mg} / \mathrm{mL}$ gentamicin sulfate (Sigma, USA). The cells were expelled from the spleen by maceration and $5 \mathrm{~mL}$ of lysis buffer (amonium chloride $0.16 \mathrm{M}$, Tris $0.17 \mathrm{M}$ ) were added to the cells, which stand for 5 minutes at room temperature (Hurrell 1988). The cells were then transferred to a tube and centrifuged once for 5 minutes, at $200 \mathrm{xg}$, at $25^{\circ} \mathrm{C}$. The pellet was resuspended and part of the cells was frozen according to Marusich (1988) with modifications: dimethyl sulfoxide (DMSO, Sigma, USA), RPMI 1640 and fetal bovine serum (FBS, Gibco, USA) were added to the cells prior to storage at $-80^{\circ}$, at a cell concentration of $1.0 \times 10^{7}$ cells $/ \mathrm{mL}$.

Culture of macrophages from Swiss SPF mice. Swiss SPF mice were sacrificed by cervical dislocation (AVMA 2001) and the peritoneal cavity was rinsed three times with warm RPMI 1640 supplemented with HAT $(100 \mathrm{~mL}$ RPMI 1640 medium $+2.4 \mathrm{~mL}$ HAT - Sigma, USA - plus 15\% FBS, $16.1 \mathrm{~g} / \mathrm{mL}$ bovine insulin - Sigma, USA, $10 \mathrm{mg} / \mathrm{mL}$ tetracycline, $1 \mathrm{mg} / \mathrm{mL}$ amphotericin $\mathrm{B}$ and $40 \mathrm{mg} / \mathrm{mL}$ gentamicin sulfate).

Culture of myeloma line Sp2/0-Ag14. The Sp2/0-Ag14 myeloma cell line (ATCC CRL 1581, American Type Culture Collection, USA, Köhler \& Milstein 1975) was previously thawed, cultured in pre-fusion medium (100mL RPMI-1640 supplemented with $10 \%$ FBS and $20 \mu \mathrm{g} / \mathrm{mL}$ 8-azaguanine, Sigma, USA), in an incubator at $37^{\circ} \mathrm{C}$ with $5 \% \mathrm{CO}_{2}$ for seven days. Then, the cells were cultured for seven more days in basal medium (RPMI 1640 supplemented with 10\% FBS).

Fusion. Fusion was performed according to Harlow \& Lane (1988) using fresh and thawed spleen cells (Marusich 1988). Fourteen days after fusion, the screening of hybridomas was initiated using indirect ELISA to detect antibodies against $C$. fetus subsp. venerealis (Harlow \& Lane 1988, Coligan et al. 1998).

Indirect ELISA to detect Campylobacter fetus subsp. venerealis. Microtiter plates with flat bottom (PoliSorp ${ }^{\mathrm{TM}}$, Nunc, Danmark) were coated with the sonicated antigen of $C$. fetus subsp. venerealis NCTC 10354 , at $3 \mathrm{ng} / \mu \mathrm{L}$, diluted in carbonate/bicarbonate buffer $0.05 \mathrm{M} \mathrm{pH} 9.6$, at $4^{\circ} \mathrm{C}$, overnight. The volume for all assay steps was of $100 \mu \mathrm{L} /$ well. After washing the plates with washing solution (saline- $\mathrm{NaCl}+0.05 \%$ Tween 20 ) they were blocked with blocking buffer - 0.1M PBS pH $7.4+3 \%$ bovine serum albumin and $0.05 \%$ Tween 20 , at $37^{\circ} \mathrm{C}$, for $1 \mathrm{~h}$. 
The hybridoma supernatant were added to the plates, and incubated at $37^{\circ} \mathrm{C}$ for 90 minutes. Plates were washed as previous described and conjugate (anti-mouse IgG conjugated with peroxidase, Sigma, USA), diluted in 1:20,000 in incubation buffer $(0.1 \mathrm{M}$ PBS $+0.1 \%$ Tween 20 ), was added and the plates incubated for 1 h at $37^{\circ} \mathrm{C}$.

The substrate ortophenilenediamine (OPD, Sigma, USA) was added at $40 \mathrm{mg} / 100 \mathrm{~mL}$, in $0.15 \mathrm{M}$ citrate buffer $\mathrm{pH} 5.0$, and the plates incubated for $1 \mathrm{~h}$ at $37^{\circ} \mathrm{C}$. The reaction was stopped with $50 \mu \mathrm{L} /$ well of $0.37 \mathrm{mM}$ sulphuric acid. Absorbance was read at $492 \mathrm{~nm}$ in an ELISA reader (Labsystems Multiskan MS 352, Finland).

Cell freezing. The hybrids were frozen according to Campbell et al. (1984), with modificatons. The freezing medium was HAT supplemented with $5 \%$ of DMSO. The hybridomas were kept at the Cell Bank of the Molecular and Cell Biology Laboratory, FUNED.

Cloning of the hybrid cells. The cloning of the hybridomas was performed by the limiting dilution procedure according to Harlow \& Lane (1988) and the positive hybrids were frozen according to Campbell et al. (1984), with modificatons. The freezing medium was HAT supplemented with 5\% of DMSO. The hybridomas were kept at the Cell Bank of the Molecular and Cell Biology Laboratory, FUNED.

Isotype characterization of monoclonal antibodies. The isotype characterization (classes and subclasses) of the produced MAbs were determined by ELISA as described (Harlow \& Lane 1988). Briefly, after the addition of hybridoma supernatants to the plates (PoliSorp ${ }^{\text {TM }}$, Nunc, Danmark), sensitized with sonicated antigen of $C$. fetus subsp. venerealis NCTC 10354 at a concentration of $3 \mathrm{ng} / \mu \mathrm{L}, 50 \mu \mathrm{L}$ of of each specific MAbs against mouse IgA, IgM, IgG $, I g G_{2 a}, I g G_{2 b}$ and $\operatorname{IgG}_{3}$ (BD Biosciences Pharmingen, EUA) $(2 \mu \mathrm{L} / \mu \mathrm{L})$ were added per well and the plates were incubated at room temperature for $1 \mathrm{~h}$. The plates were then washed three times with PBS $+0.5 \%$ Tween 20 , and $50 \mu \mathrm{L}$ of anti-rat IgG peroxidase conjugate (Sigma, USA), diluted 1:10,000 in incubation buffer, were added to each well, followed by incubation for $1 \mathrm{~h}$ at $37^{\circ} \mathrm{C}$. Reactions were detected with OPD as previously described.

Characterization of the monoclonal antibody specificity. The specificity of the MAbs were assayed by indirect ELISA with sonicated antigens from Arcobacter skirrowii LMG 6621, C. fetus subsp. fetus ADRI 1812, C. fetus subsp. venerealis NCTC 10354, C. lari NCTC 11351, C. sputorum biovar sputorum LMG 6647. The MAbs reacting only against $C$. fetus antigens were also tested by western blot using sonicated antigens of $C$. fetus subsp. venerealis NCTC 10354 and C. sputorum biovar sputorum LMG 6647.

Sodium dodecyl sulfate-polyacrylamide gel electrophoresis (SDS-PAGE) and Western blot. SDS-PAGE was perfomed as previously described (Laemmli 1970) using sonicated antigens from C. fetus subsp. venerealis NCTC 10354 and C. sputorum biovar sputorum LMG 6647. After electrophoresis, the separated antigens were transferred to a nitrocellulose membrane (Harlow \& Lane 1988), at $100 \mathrm{~V}$, for $1 \mathrm{~h}$. Then, the nitrocellulose was washed three times with washing buffer (Tris saline plus $0.05 \%$ Tween 20 -TBST, pH 7.5), for 5 minutes at room temperature. The nitrocellulose membrane was blocked with TBS pH $7.5+1.0 \%$ Tween 20 for $1 \mathrm{~h}$ at room temperature. The nitrocellulose membane was packed in Mini Protean®II Multi Screen (BioRad, EUA.) apparatus. The hybridoma supernatants $(50 \mu \mathrm{L})$ were added to the wells and incubated for $3 \mathrm{~h}$ at room temperature. After washing, the conjugate anti- mouse IgG peroxidase, at 1:5.000 diluiton in 0.1\% TBST, was added and the membrane was incubated for $1 \mathrm{~h}$ at room temperature and developed with the substrate 3,3'-diaminobenzidine (DAB, Kit DAB SK-4100, Vector Laboratories, EUA) following the manufacturer's instructions.

\section{RESULTS}

Fusion with primed frozen spleen cells (Marusich 1988) resulted in no hybrids. The fusion with primed fresh spleen cells resulted in hybrids and the production of MAbs. Fourteen days after fusion, positive clones secreting antibodies anti-Campylobacter fetus subsp. venerealis were detected by indirect ELISA. After limiting dilution, 15 wells of the hybrid cells were positive for antibody against $C$. fetus subsp. venerealis.

Fourteen of the anti-C. fetus producing clones were of the IgG class, with subclasses $\operatorname{IgG}_{1}\left(13\right.$ clones) and $\operatorname{IgG}_{2 \mathrm{~b}}(1$ clone), and one clone was of the IgM class (Table 1).

Results of the specificity characterization of the produced MAbs against antigens from Arcobacter skirrowii LMG 6621, C. fetus subsp. fetus serotype A ADRI 1812, C. fetus subsp. venerealis NCTC 10354, C. lari NCTC 11351 and $C$. sputorum biovar sputorum LMG 6647 are shown in Table 1.

The four producing clones of species-specific antibodies, M28 and M93, against C. fetus subsp. venerealis, and M7 and M94, specific for $C$. fetus subsp. fetus, were characterized by western blotting. The results showed that all clones recognized an immunogenic band with a molecular weight of approximately $148 \mathrm{kDa}$ from the $C$. fetus subsp. venerealis antigen (Fig.1). No reactivity was observed with the antigen of $C$. sputorum biovar sputorum (data not shown).

\section{DISCUSSION}

The development in making of MAbs has greatly improved the production of specific and homogeneous antibodies. MAbs against microorganisms are important tools for the diagnosis and study of epidemiology and host-parasite relation in infectious diseases, such as those caused by Campylobacter fetus subsp. venerealis.

The protocol using primed frozen spleen cells (Marusich 1988) might constitute an interesting option for MAb production, as a sole spleen could be used at different times

Table 1. Specificity and isotype of monoclonal antibodies produced against Campylobacter fetus subsp. venerealis NCTC 10354

\begin{tabular}{|c|c|c|c|c|c|c|}
\hline \multirow[t]{2}{*}{ Clones } & \multicolumn{5}{|c|}{ Strains $^{\mathrm{a}}$} & \multirow[t]{2}{*}{ Isotype } \\
\hline & LMG 6647 & NCTC 10354 & ADRI 1812 & NCTC 11352 & LMG 6621 & \\
\hline M2 & $-b$ & $+^{c}$ & + & + & - & $\operatorname{IgG}_{1}$ \\
\hline M7 & - & - & + & - & - & $\operatorname{IgM}$ \\
\hline M21 & - & + & + & + & - & $\operatorname{IgG}_{1}$ \\
\hline M22 & - & + & + & + & - & $\operatorname{IgG}_{1}$ \\
\hline M28 & - & + & - & - & - & $\operatorname{IgG}_{1}$ \\
\hline M37 & - & + & + & + & - & $\operatorname{IgG}_{1}$ \\
\hline M39 & - & + & + & + & - & $\operatorname{IgG}_{1}$ \\
\hline M41 & - & + & + & + & - & $\operatorname{IgG}_{1}$ \\
\hline M42 & - & + & + & + & - & $\operatorname{IgG}_{1}$ \\
\hline M44 & - & + & - & + & + & $\operatorname{IgG}_{1}$ \\
\hline M45 & - & + & + & + & + & $\operatorname{IgG}_{2 \mathrm{~b}}$ \\
\hline M60 & - & + & + & + & - & $\operatorname{IgG}_{1}$ \\
\hline M76 & - & + & + & + & - & $\operatorname{IgG}_{1}$ \\
\hline M93 & - & + & - & - & - & $\operatorname{IgG}_{1}$ \\
\hline M94 & - & - & + & - & - & $\operatorname{IgG}_{1}$ \\
\hline
\end{tabular}

a Strains: Arcobacter skirrowii LMG 6621, C. fetus subsp. fetus serotype A ADRI 1812, C. fetus subsp. venerealis NCTC 10354, C. hyointestinalis subsp. hyointestinalis LCDC 17398, C. lari NCTC11351, C. sputorum biovar sputorum LMG 6647; b “-” - no recognition; c “+” - recognition. 


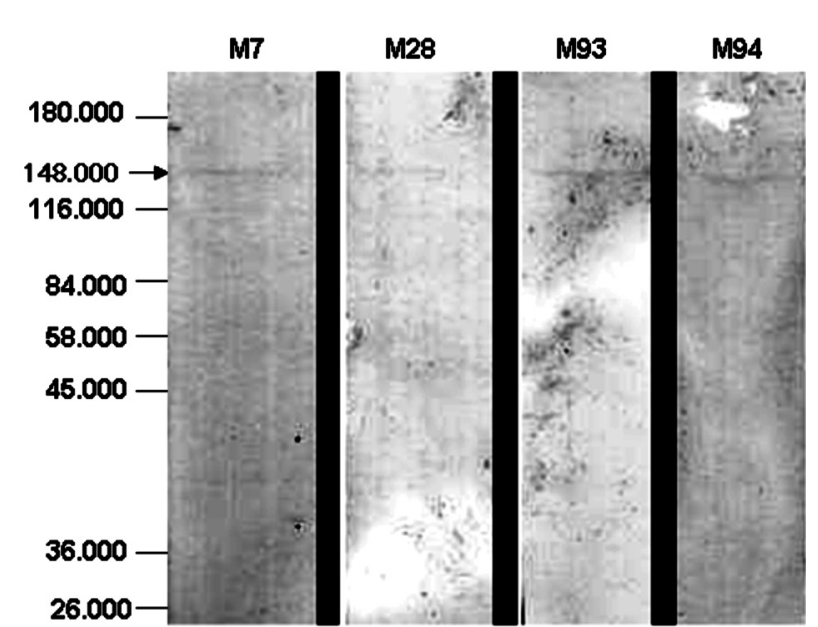

Fig.1. Western blotting for the characterization of monoclonal antibodies obtained from species-specific clones. Western blotting using sonicated Campylobacter fetus subsp. venerealis NCTC 10354 antigen $(357 \mu \mathrm{g}$ per lane) and $2000 \mu \mathrm{L}$ of supernatant of culture clones M7 (lane 1), M28 (lane 2), M93 (lane 3), and M94 (lane 4). Reactions were performed using anti-mouse IgG peroxidase conjugate (Sigma, USA) and revealed by DAB kit (Vector Laboratories, USA). Arrow indicates the 148 kDa recognized band. Marker: Prestained Molecular Weight Standard mixture (Sigma, USA).

for fusion to obtain clones, therefore minimizing the use of mice. However, with the modified protocol used in the present study, no successful hybrid cell was obtained. Spleen cells were kept frozen for more than 2 years at $-80^{\circ} \mathrm{C}$ in contrast with the prescribed storage at liquid nitrogen. Also, spleen cells were frozen in supplemented RPMI 1640 instead of HGDMEM supplemented medium. These differences could explain the failure in obtaining hybrid cells from frozen spleen cells. Many cell types stored at temperatures less than or around $-80^{\circ} \mathrm{C}$ had their metabolism decreased, however to a level insufficient to halt all intracellular chemical reactions. This could result in the formation of intracellular ice crystals and damage of cellular structures, leading to cell death (Mazur 1984, Fowler \& Toner 2005). However, for most of the cell types, freezing at $-196^{\circ} \mathrm{C}$ halts cell metabolism as there is no liquid water and sufficient thermal energy for chemical reactions to occur, increasing the cell survival rates (Mazur 1984, Fowler \& Toner 2005). RPMI 1640 medium has a lower concentration of glucose and sodium piruvate that could represent readly available energy sources for unfrozen cells. Moreover, $\beta$-mercaptoethanol, insulin and the supernatant of P388D 1 cell culture (Bazin \& Lemieur 1989) present in HGDMEM supplemented medium could have, respectively, facilitated cell fussion and stimulated energy metabolism and plasma cell proliferation. Irreversible damage to the cells could have occurred resulting in failure of hybrid cell production from frozen cells.

The fusion protocol used (Harlow \& Lane 1988), performed with fresh spleen cells, resulted in antibody producing hybridomas, needing no feeder cells, due to their excellent growth and satisfactory number of cells to perform the cloning.

The predominance of MAb producing clones of the IgG class was expected due to the immunization scheme. The use of complete and incomplete Freund adjuvants stimulate, respectively, predominant Th1 and Th2 responses with their high mainly associated production of IgG2a and IgG1(Harlow \& Lane 1988, Chang et al. 1998).

For the specificity studies, a panel of antigens was chosen based on the prevalences and habitats of bacteria from genera Campylobacter and Arcobacter. C. sputorum biovar sputorum is a commensal of the prepuce of bulls, being found in prepucial washings, which can mislead the diagnosis of $C$. fetus subsp. venerealis infection in bulls (Debruyne et al. 2008, Stoessel 1982). C. fetus subsp. fetus is the closest related to $C$. fetus subsp. venerealis, which inhabits the gastrointestinal tract of cattle and could also be found in the prepuce of bulls and in aborted fetuses from cattle (Blaser et al. 2008). The strain of $C$. fetus subsp. fetus used, ADRI 1812, is from serogrup A, to which all strains of $C$. fetus subsp. venerealis belong (Stoessel 1982). C. lari is an intestinal bacteria found in animals and humans. Arcobacter skirrowii can also be found in the prepuce of bulls being already isolated from aborted bovine fetus (Vandamme et al. 1992). Thus, results from the present study shows that MAbs obtained against $C$. fetus subsp. venerealis do not cross react with other bacteria of the Campylobacteracae family that could be frequently present in the prepuce of bulls or in aborted bovine fetuses.

In the western blotting, no reactivity against the $C$. sputorum biovar sputorum was observed (data not shown) with the MAbs from the four species-specific clones, confirming again their specificity. Reactivity was observed against a protein of aproximately $148 \mathrm{kDa}$ from $C$. fetus subsp. venerealis. According to Dunn etal. (1987), proteins as the flagelum, with molecular mass of $63 \mathrm{kDa}$, proteins of the outer membrane of low molecular mass, variyng from 43 to $44 \mathrm{kDa}$, and glycopolisacharides, with $100 \mathrm{kDa}$, are important for immunogenicity against $C$. fetus. In $C$. fetus, imunnologically relevant proteins are also found in a microcapsule-like structure named "S" layer that contains subunits of a protein known as SAP (surface array protein), formed by proteins of high molecular mass, varying from 97 to $149 \mathrm{kDa}$ (Garcia et al. 1995). The "S" layer covers immunogenic structures of $C$. fetus including lipopolissacharides and outer membrane proteins (Dunn et al. 1987, Garcia et al. 1995, Blaser et al. 2008). Changes in the "S" layer could explain the production of surface components with different antigenic specificities, which characterizes an evasion mechanism of the microorganism against the host immune system, allowing the $C$. fetus infection to persist longer (Blaser et al. 2008). Due to the SAP's high immunogenicity and the varying molecular weight, MAbs produced against C. fetus could probably be directed to SAP.

MAbs against Campylobacter fetus produced in the present study could constitute important tools for the development of diagnostic tests and also for characterization of $C$. fetus in studies of host-parasite relationship.

Acknowledgements.- T.M. Alves and A.P. Lage were supported by fellowships from Conselho Nacional of Desenvolvimento Científico and Tecnológico (CNPq). This study received financial support from Fapemig and FEP-MVZ Coordenação Preventiva. All ADRI strains used in the present study were kindly supplied by Dr. B. Brooks. We thank C.P.T. de Brito and A. Fernandes for technical assistance. 


\section{REFERENCES}

Alves T.M., Stynen A.P.R., Miranda K.L. \& Lage A.P. 2011. Campilobacteriose genital bovina e tricomonose genital bovina: epidemiologia, diagnóstico e controle. Pesq. Vet. Bras. 31(4):336-344.

AVMA 2001. Report of the AVMA Panel on Euthanasia. J. Am. Vet. Med. Assoc. 218(5):669-696.

Bazin R. \& Lemieux R. 1989. Increased proportion of B cell hybridomas secreting monoclonal antibodies of desired specificity in cultures containing macrophage-derived hybridoma growth factor (IL-6). J. Immunol. Meth. 116:245-249.

Blaser M.J., Newell D.G., Thompson S.A. \& Zechner E.L. 2008. Pathogenesis of Campylobacter fetus, p.401-428. In: Nachamkin I., Szymanski C.M. \& Blaser M.J. (Eds), Campylobacter. $3^{\text {rd }}$ ed. ASM, Washington.

Campbell A.M. 1984. Monoclonal Antibody Technology. Elsevier Science Publishers, Amsterdam. 265p.

Chang J.C.C., Diveley J.P., Savary J.R. \& Jensen F.C. 1998. Adjuvant activity of incomplete Freund's adjuvant. Adv. Drug. Deliv. Rev. 32:173-186.

Coligan J.E., Kruisbeek A.M., Margulies D.H., Shevach E.M. \& Strober W. 1998. Current protocols in immunology. Vol.1. John Wiley and Sons, New York.

Debruyne L., Gevers D. \& Vandamme P. 2008. Taxonomy of the family Campylobacteraceae, p.3-25. In: Nachamkin I., Szymanski C.M. \& Blaser M.J. (Eds), Campylobacter. $3^{\text {rd }}$ ed. ASM, Washington, DC.

Dunn B.E., Blaser M.J. \& Snyder E.L. 1987. Two-dimensional gel electrophoresis and immunoblotting of Campylobacter outer membrane proteins. Infect. Immun. 55(7):1564-1572.
Fowler A. \& Toner M. 2005. Cryo-injury and biopreservation. Ann. N.Y. Acad. Sci. 1066(1):119-135.

Garcia M.M., Lutze-Wallace C.L., Denes A.S., Eaglesome M.D., Holst E. \& Blaser M.J. 1995. Protein shift and antigenic variation in the S layer of Campylobacter fetus subsp. venerealis during bovine infection accompanied by genomic rearrangement of sapA homologs. J. Bacterol. 177(8):1976-1980.

Harlow E.D. \& Lane D. 1988. Antibody: A laboratory manual. Cold Spring Harbor Laboratory, New York. 726p.

Hurrell J.G.R. 1988. Monoclonal Hibridoma Antibodies: Techniques and applications. Cold Spring Harbor Laboratory, New York. 726p.

Köhler G. \& Milstein C. 1975. Continuous cultures of fused cells secreting antibody of predefined specificity. Nature. 256:495-497.

Laemmli U.K. 1970. Cleavage of structural proteins during the assembly of the head of bacteriophage T4. Nature 227:680-686.

Lowry H.L., Rosebrough N.J. \& Farr A.L. 1951. Protein measurement with the folin phenol reagent. J. Biol. Chem. 193:265-275.

Marusich M.F. 1988. Efficient hybridoma production using previously frozen splenocytes. J. Immunol. Meth. 144:155-159.

Mazur P. 1984. Freezing of living cells: Mechanisms and implications. Am. J. Physiol. 247:125-142.

Stoessel F. 1982. Las enfermedades venereas de los bovinos: trichomoniasis y vibriosis genital. Acribia, Zaragoza. 163p.

Vandamme P., Vancanneyt M. \& Pot B. 1992. Polyphasic taxonomy study of the enmended genus Arcobacter with Arcobacter butzleri comb. nov. and Arcobacter skirrowii sp. nov., an aerotolerante bacterium isolated from veterinary specimens. Int. J. Syst. Bacteriol. 42:344-356. 